\title{
Gene Expression and In Vitro Selection for Salinity Tolerance in Peanut Dhuha, S. M., Adel, S. Taghian, Hamdy, M. El-Aref and Bahaa, E. Abd-El-
} Fatah

Dept. of Genetics, Faculty of Agriculture, Assiut University, Assuit, Egypt.

\begin{abstract}
:
Peanut (Arachis hypogaea L.) is considered to be one of the most important edible oil crops in the world as well as in Egypt. In the present study, tissue culture protocol was established in peanut varieties and the in vitro selection was applied to assess the possibility of obtaining salt tolerant peanut plants via tissue culture. In addition, the change in gene expression under salinity stress as revealed by protein pattern analyses was also studied. Callus and shoot regeneration were decreased with the increment of $\mathrm{NaCl}$ level from 50 to $150 \mathrm{mM}$ in the culture medium. At higher concentration of $\mathrm{NaCl}(200 \mathrm{mM})$, the cultured explants turned brown and the few developed calli failed to regenerate shoots or regenerated abnormal shoots with very low frequency in all tested varieties. A total of 1760 embryonated cotyledons from Giza-5, Gregory, Giza-7 and Giza-6 were cultured under selection conditions of salinity stress $(150 \mathrm{mM} \mathrm{NaCl})$. The selected and unselected regenerated plants in comparison to their donor parents were tested for salinity tolerance in vitro by culturing on medium supplemented with 0.0 and $150 \mathrm{mM} \mathrm{NaCl}$. The selected plants showed significant enhancement in their growth under salinity treatment, as compared with the unselected plants and their donor parents. Salinity stress treatment lead to differential expression of the genetic information in peanut, resulting from changes in gene products, including the synthesis of four new proteins and simultaneously reduced the expression of 8 proteins in the tested varieties. The newly synthesized proteins may play an important role in the mechanism(s) of salt tolerance in peanut.
\end{abstract}

Keywords: Peanut, Arachis hypogaea L., in vitro selection, salinity, gene expression, protein pattern.

Received on:12/3/2014

Accepted for publication on:19/3/2014

Referees: Prof. Effat M. M. El-farrash

Prof. Mohamed Y. Hussein 


\section{Introduction:}

Peanut (Arachis hypogaea L.; allotetraploid AABB, $2 \mathrm{n}=4 \mathrm{x}=40$ ) is considered to be one of the most important edible oil crops in Egypt, due to its seeds high nutritive value for human and the produced cake as well as the green leafy hay for livestock, in addition to the seed oil importance for industrial purposes. Peanut contains about $50 \%$ edible oil, $25-28 \%$ protein, $20 \%$ carbohydrates and 5\% fiber (Gohari \& Niyaki, 2010).

As excessive salinity concentration in the soil is one of the major problems for cultivated lands, much effort has been directed toward the development of salt tolerant plants. Most crop plants, including the cultivated peanut, are sensitive to salinity, although differences between peanut cultivars have been reported (Mungala et al., 2008 and Xiao-hui et al., 2011). One strategy to reduce the deleterious effects of soil salinity on peanut production is the development of salttolerant cultivars (Feng-zhen et al., 2003 and Ghauri 2006).

Cell and tissue cultures have been regarded as a useful tool to obtain and study lines tolerant to biotic and abiotic stresses, by exploiting the genetic variability arising during in vitro culture conditions (Buiatti et al., 1984). Selection for salinity tolerance can be carried out in vitro, by culturing either explants, callus pieces, cell suspension, protoplasts, embryos or microspores in the presence of screening agent, e.g. $\mathrm{NaCl}$ (Cano et al., 1996). In vitro selection and screening for salinity tolerance have been reported in peanut by (Sarin et al., 1991; Fengzhen et al., 2003; Ghauri, 2006 and Mungala et al., 2008).

The effects of salt stress on plants show many physiological and molecular processes, e.g. altering the gene expression, decreasing the protein synthesis and/or increasing protein hydrolysis. This could lead to reduce DNA replication and cell division, and consequently reducing the plant growth and yield (Hassanein, 1999 and El-Aref, 2002). Changes in gene expression can be detected by studying the protein pattern in which appearance or disappearance of protein band and increasing or decreasing of band intensity marks if there is a change in the gene expression. (Khavkin and Zabrodina, 1994 and El-Aref, 2002). Changes in protein patterns have been well documented under salinity stress in peanut (Muthukumarasamy and Panneerselvam, 1997; Hassanein, 1999 and Jain et al., 2006).

The present study aimed to assess the possibility of obtaining salt tolerant peanut plants via tissue culture. In addition, the changes in gene expression under salinity stress as revealed by protein analyses were also studied.

\section{Materials and Methods:}

Plant Materials: Six genotypes of peanut (Arachis hypogea L.) namely, Ismailia-1 (G1), Giza-5 (G2), Agryl (G3), Gregory (G4), Giza-7 (G5) and Giza-6 (G6) were used in the present investigation.

Tissue culture: Mature seeds were surface-sterilized by soaking in $70 \%$ ethanol for $4 \mathrm{~min}$, followed by a wash for $25 \mathrm{~min}$ in $0.1 \%(\mathrm{w} / \mathrm{v})$ mercuric chloride solution. Then, seeds were rinsed three times in sterile distilled water and soaked in sterile distilled water for $2 \mathrm{~h}$ before further use. With forceps and under aseptic conditions, seed coats were carefully removed. Cotyledons were separated into two halves. The cotyledon half containing the embryo axis was designated as "emberyonated cotyledon explant". The explants were then embedded 
into shoot induction medium [MS salts, B5 vitamins, 25mg N6- benzyladenine (BA), $3 \%(\mathrm{w} / \mathrm{v})$ sucrose and $0.8 \%(\mathrm{w} / \mathrm{v})$ agar, $\mathrm{pH} 5.8]$. Cultures were incubated at $24 \pm 2^{\circ} \mathrm{C}$ under continuous illumination derived from cool white fluorescent. After $3-4$ weeks of culture, responded explants were cut and sub-cultured on the same medium for another $2-3$ weeks for shoot induction. Regenerated shoots were cultured on the same shoot induction medium for shoot elongation. After $2-3$ weeks, shoots ( $3-5 \mathrm{~cm}$ long) were transferred to root induction medium containing MS salts, B5 vitamins, $1 \mathrm{mg}$ naphthalene acetic acid (NAA), 3\% $(\mathrm{w} / \mathrm{v})$ sucrose and $0.8 \%(\mathrm{w} / \mathrm{v})$ agar at $\mathrm{pH} 5.8$ for three weeks.

In vitro response of peanut genotypes for salt stress: the experiment was carried to study the response of peanut genotypes for salinity stress and to determine the suitable concentration of sodium chloride for in vitro selection. Two hundreds of peanut explants from the six varieties were cultured on regeneration medium supplemented with $0.0,50,100,150$ and $200 \mathrm{mM} \mathrm{NaCl}$ media. After 8 weeks of incubation, the percentage of callus formation and shoot regeneration were recorded. From this experiment, it was decided to use the concentration 150 $\mathrm{mM} \mathrm{NaCl}$ as a selection stress ( $\sim 10 \%$ response of the control) to enhance salt tolerance in peanut.

In vitro selection for salinity tolerance: A total of 1760 embryonatedcotyledons (440 explants/genotype) taken from the four varieties Giza-5, Gregory, Giza-7 and Giza- 6 were cultured on the regeneration medium supplemented with $150 \mathrm{mM} \mathrm{NaCl}$. The cultures were incubated in the culture room at $25 \pm 2^{\circ} \mathrm{C}$ under 16/8 light regime for eight weeks. Callus formation and Shoot regeneration were developed on the same salinized medium. While, the selected shoots were rooted on rooting medium free of $\mathrm{NaCl}$ stress. After 4-6 weeks, the rooted shoots were transferred to MS medium free of growth hormones and $\mathrm{NaCl}$ stress for growth and further development. Control treatment was made by culturing 200 explants/genotype on $\mathrm{NaCl}$ free shoot induction medium.

Salinity tolerance test: Plants regenerated from the tested varieties on control: (unselected) and salinized (selected plants) mediums as well as their donor parents were evaluated in vitro for salt tolerance. The fresh weight of the tested plants were determined under aseptic condition, then plants were transferred immediately to control (MS free of $\mathrm{NaCl}$ ) and salinized (MS $+150 \mathrm{mM} \mathrm{NaCl})$ medium. The experiment was designated in a randomized complete block with three replicates. The cultures were incubated in the culture room for two weeks at $25 \pm 2^{\circ} \mathrm{C}$ under $16 / 8$ light regime. After that, fresh weight was determined and the mean increase in plant growth was calculated.

\section{Changes in gene expression under salinity stress:}

Soluble protein was determined in order to study the changes in gene expression under salinity stress. Sterilized seeds of the Giza-5, Gregory and Giza-7 were cultured on MS medium supplemented with 0.0 and $150 \mathrm{mM} \mathrm{NaCl}$ and incubated for two weeks at $25 \pm 2{ }^{\circ} \mathrm{C}$ under $16 / 8$ light regime. Soluble proteins were extracted from the developed seedlings of the tested varieties using equal volumes of extraction buffer $(0.1 \mathrm{M}$ Tris-Hcl $+2.0 \mathrm{mM}$ EDTA $+2 \%$ glutathion, $\mathrm{pH}$ 7.8). Protein analysis by electrophoresis was carried out according to the method of Laemmli (1970) with $12 \%$ polyacrylamide and $1 \%$ SDS (w/v) under denaturing conditions. The gel was stained for protein bands with Commassie Blue R. 
Then, gel was destained by repeated immersion in a mixture of methanol: acetic acid: water (1:1:8, by volume). Data were obtained by scanning densitometer Gene Profiler-Evl electrophoresis data system program.

\section{Results and Discussion:}

Peanut tissue culture:

Different explants (e.g. emberyonated and de-emberyonated cotyledons) and growth hormones were tested to establish the protocol of tissue culture in 6 varieties of peanut. The emberyonated cotyledons and MS medium supplemented with $25.0 \mathrm{mg} / 1 \mathrm{BAP}$ were superior in callus formation and number of shoots per explant and were more suitable for regeneration of peanut plants than the others tested. In addition, the high efficiency of root formation was obtained by culturing of regenerated shoots on MS medium supplemented with $1.0 \mathrm{mg} / 1 \mathrm{NAA}$. The different stages of in vitro development of peanut regenerated plants from the embryonated cotyledon explant are shown in Fig. (1).

\section{In vitro response of peanut genotypes for salinity stress:}

The mean values of callus formation percentage and number of shoots/explant from embryonated cotyledons of the six peanut varieties after four weeks of culture on control $(0.0 \mathrm{NaCl})$ and salinized $(50,100,150$ and $200 \mathrm{mM}$ $\mathrm{NaCl}$ ) media are given in table (1). While table (2) display the analysis of variance of these results.

Averaged over the tested varieties, callus formation and shoot regeneration were adversely affected by the increments of salinity stress in the culture medium. The highest percentage of callus formation (68.33\%) was obtained from the control treatment. This percentage was decreased to $58.00 \%, 29.44 \%$, $12.33 \%$ and $2.13 \%$ under 50, 100,150 and $200 \mathrm{mM} \mathrm{NaCl}$, respectively. Similarly, shoot regeneration was reduced from: 10.15 shoots/explant on control medium to: $7.10,3.42,1.03$ and 0.32 shoots/explant on: 50, 100, 150 and $200 \mathrm{mM}$ $\mathrm{NaCl}$, respectively. These differences between the levels of $\mathrm{NaCl}$ were highly significant (Table 2).

The results also revealed significant differences between the tested varieties in callus and shoot formation under different salinity stress treatment (Table 2). At low level of salt stress $(50 \mathrm{mM} \mathrm{NaCl})$, the varieties showed variable response ranged from reduction to enhancement of callus formation (Table 1). Salt stress $(50 \mathrm{mM} \mathrm{NaCl})$ reduced callus formation to be $97.60 \%, 76.46 \%, 68.01 \%$ and $60.87 \%$ of the control treatment in Giza-5, Giza-6, Gregory, and Giza-7, respectively. Meanwhile, this low level of $\mathrm{NaCl}$ enhanced callus formation in Ismailia1 (114.27\% of the control) and Agryl (105.27\% of the control). Although, these two varieties showed enhancement in callus formation under low level of salinity stress, they displayed high reduction in callus formation under high levels of $\mathrm{NaCl}$ than the other varieties. Callus formation ranged from 10.0\% (Ismailia-1) to $60.00 \%$ (Giza-5) on $100 \mathrm{mM} \mathrm{NaCl}$, from $3.0 \%$ (Agryl) to $21.67 \%$ (Giza-7) on $150 \mathrm{mM} \mathrm{NaCl}$ and from $0.1 \%$ (Ismailia-1) to $6.67 \%$ (Giza-7) on $200 \mathrm{mM} \mathrm{NaCl}$. Shoot regeneration as expressed as number of shoots/explant ranged from 8.12 (Ismailia-1) to 12.0 (Giza-5) on control medium, from 4.67 (Agryl) to 9.67 Giza5 and Gregory) on $50 \mathrm{mM} \mathrm{NaCl}$, from 1.33 (Ismailia-1) to 6.17 (Giza-5) on 100 $\mathrm{mM} \mathrm{NaCl}$, from 0.27 (Agryl) to 1.6 (Giza-5) on $150 \mathrm{mM} \mathrm{NaCl}$ and from 0.1 (Ismailia-1) to 0.47 (Giza-5 and Giza-7) on $200 \mathrm{mM} \mathrm{NaCl}$. These results indi- 
cated that Ismailia-1 and Agryl were highly sensitive to salinity stress than the other varieties.

Feng-zhen et al., 2003 found that callus formation from peanut leaves was remarkably suppressed on $4 \mathrm{~g} / 1 \mathrm{NaCl}$ and completely suppressed on $10 \mathrm{~g} / \mathrm{l}$. They also found that the remarkably and completely suppress shoot regeneration and adventitious root formation was $6 \mathrm{~g} / 1$ and $8 \mathrm{~g} / 1$, respectively. Similarly, Ghauri, 2006 reported that the percentage of shoot regeneration decreased with the increase of $\mathrm{NaCl}(0.1-0.5 \%)$ in the shoot regeneration medium. While, root formation in these cultures was only took place when the cultures were nurtured on MS medium free of growth hormones.

Generally, the above results (Table 1) revealed that the development of callus and its differentiation were decreased with the increment of $\mathrm{NaCl}$ level from 50 to $150 \mathrm{mM}$. At higher concentrations, almost all the cultured explants turned brown and the few developed calli failed to regenerate shoots or regenerate abnormal shoots with very low frequency in all tested varieties. Therefore, it was decided to use the concentration $150 \mathrm{mM} \mathrm{NaCl}$ as a selection stress $(\sim 10 \%$ response of the control) to enhance salt tolerance in peanut.

\section{In vitro selection for salinity tolerance in peanut genotypes}

From the four genotypes, 1760 embryonated cotyledons were cultured under selection conditions and 800 cotyledons cultured on control medium (Table 3 ). Callus formation and shoot regeneration varied from one cultivar to another and from control medium to the salt stressed medium. In general, the percentage of callus formation was sharply reduced from $58.25 \%$ in salt-free medium to $16.70 \%$ in salt stressed medium $(150 \mathrm{mM} \mathrm{NaCl})$, as averaged over the four tested varieties. Similarly, the number of shoots/explant was sharply reduced from 9.57 shoots in salt-free medium to 1.45 shoots in salt stressed medium. These results revealed that the percent of regeneration was reduced under salinity stress to be $28.67 \%$ (71.33\% reduction) in callus and $15.15 \%$ (84.85\% reduction) in shoot formation of that on the control treatment. These results indicated clearly that the presence of sodium chloride in the culture medium may inhibit the regeneration process in peanut. Sarin et al., (1991) succeeded in inducing an Arachis hypoagaea callus line tolerant to $200 \mathrm{mM} \mathrm{NaCl}$ by culturing the callus on media containing 50, 100 and $150 \mathrm{mM} \mathrm{NaCl}$. Kumar et al., (2001) selected $\mathrm{NaCl}$ tolerant calli (variants) from the cotyledonary embryo of peanut (A.hypogaea L.) on agar solidified medium supplemented with $1 \% \mathrm{NaCl}$, a concentration otherwise lethal to non-selected calli.

In vitro- selected cell lines, even when verified for salt tolerance, have often been found to lose their regeneration potential (Meredith, 1984; and McCoy, 1987). Perhaps for this reason, regeneration was drastically inhibited and the embryogenic callus failed to regenerate shoots when $\mathrm{NaCl}$ was found in the regeneration medium (Kirti et al., 1991). In addition, Ben-Hayyim and Goffer (1989) reported that regeneration of plantlets from tolerant cell lines of Citrus sinensis did not succeeded in the presence of $\mathrm{NaCl}$.

Because of the inhibitor effect of sodium chloride on the regeneration process, the selected and unselected shoots were rooted on $\mathrm{NaCl}$-free rooting medium. The number of shoots formed roots and percentage of rooting in both selected and unselected shoots from the four varieties are given in table (3). It was 
clear that the $\%$ of root formation in the selected shoots was less than the unselected shoots. In this respect, the $\%$ of root formation in the unselected shoots was 31.03, 39.03, 40.01 and 58.16\% in Giza-5, Gregory, Giza-7 and Giza-6 with an average of $42.06 \%$, respectively. While these percentages decreased to 27.12 , $32.56,33.33$ and $42.35 \%$ in the selected shoots of Giza-5, Gregory, Giza-7 and Giza- 6 with an average of $33.84 \%$, respectively.

From the tested genotypes, 32, 28, 46 and 36 plants were selected from Giza-5, Gregory, Giza-7 and Giza-6 for salinity tolerance, respectively. The selected and unselected plants from the four genotypes were maintained in vitro for further development and tested for salinity tolerance.

\section{Salinity tolerance test:}

The selected and unselected plants in comparison to their donor parents were tested for salinity tolerance in vitro by culturing on medium supplemented with 0.0 and $150 \mathrm{mM} \mathrm{NaCl}$. The mean increase in plant fresh weight after two weeks of culture on control and salinized medium are shown in table (4). While, the analysis of variance for these results is given in Table (5). In addition, figure (2) revealed the symptoms of salinity stress on peanut plants after two weeks of growth on control $(0.0 \mathrm{mM} \mathrm{NaCl})$ and salinized $(150 \mathrm{mM} \mathrm{NaCl})$ medium.

Generally, the results revealed that plants derived from donor parents, selected and unselected genotypes exhibited a low rate of growth on salinized medium as compared with the control treatment (Table 4). The analysis of variance revealed highly significant differences between all genotypes as well as between the two concentrations of $\mathrm{NaCl}$ (Table 5).

The selected plants exceeded their donor parents and the unselected plants in growth on salinized medium. Averaged over the genotypes, the mean increase in plant growth under salinity stress was $71.95 \%$ of the control in the selected plants as compared with $56.88 \%$ in their donor parents and $57.14 \%$ in unselected plants (Table 4). These differences between the selected plants and their donor parents as well as between selected and unselected plants were highly significant. These results indicated that salinity tolerance was enhanced in the selected plants as compared to the donor parents and unselected plants. However, this enhancement varied from one genotype to another. In this instance, the maximum enhancement was observed in plants selected from Giza-7 (84.61 of the control) followed by Giza-6 (78.74\%) and Giza-5 (72.09\%). While those selected from Gregory showed the lowest enhancement (55.61\% of the control) of growth under salinity stress. Similar results were also obtained by Mungala et al., (2008). The results also revealed non-significant differences in the mean increase in plant growth between the unselected plants $(57.14 \%$ of the control) and their donor parents (56.88\%; Tables 4 and 5).

In vitro selection has been proposed as a cheep methodology to screen for variants. That is the medium in which cells or tissues are grown under stress could be modified so that only cells or calli of certain variant type would survive and produce regenerated plants (Meredith, 1984 and Tal, 1984). In addition, it was found that salt tolerance expressed at the cellular level was expressed at a whole plant in peanut and breeding salt tolerant plants could be conducted at callus culture level effectively (Ghauri 2006). The use of plant tissue culture methods for screening and selecting salt-tolerant peanut calli (variants) or plants has 
been reported and discussed by several authors (Sarin et al., 1991; Kumar et al., 2001; Ghauri, 2006 and Mungala et al., 2008).

However, an important point remain to be verified, i.e., is that any such new trait that has been selected at the cellular level can be expressed at the whole plant level and then transferred to the next generation. In the present study, the embryonated cotyledons of peanut were cultured on the selective medium containing $150 \mathrm{mM} \mathrm{NaCl}$ and the subsequent callus formation and shoot regeneration were developed on the same medium. Meanwhile, root formation and further growth were carried out on $\mathrm{NaCl}$-free medium. Then, the selected plants were tested in vitro and showed salt tolerance. Thus, it could be concluded that salt tolerance has been expressed at the cellular level and the mechanism(s) of enhanced salt tolerance in peanut is stable during the course of root formation and plant development, and the selected plants showed tolerance at R0 generation, while the stability of salt tolerance needs to be examined in the next generation (R1) of the selected plants. Orton (1980) suggested relatively simple genetic bases for salinity tolerance in barley, which may be transferable by hybridization and selection, and that genes for tolerance may be additive and therefore amenable to concentration by selection. Meanwhile, Tal (1984) reported that inheritance patterns for salinity tolerance were complex and not strictly Mendelian, suggesting multiple mutational events.

In the present investigation, the selected plants showed significant enhancement in their growth under salinity treatment, as compared with the unselected plants and their donor parent. These results indicate the feasibility and effectiveness of screening and selection for salt tolerant genotypes via tissue culture in salt stressed medium. Similar results and conclusion were also reported in peanut (Ghauri, 2006 and Mungala et al., 2008) and in barley (Taghian 1992).

\section{Changes in gene expression in peanut under salinity stress:}

Since proteins comprise the majority of stable functional genetic products, the changes in gene expression by salinity stress, as revealed by electrophoretic protein analysis were studied in the three varieties Giza-5, Gregory, and Giza-7. Protein profile of the three genotypes grown under control and salinity treatments $(0.0$ and $150 \mathrm{mM} \mathrm{NaCl})$ are summarized in Table (6) and illustrated in Fig (3).

The tested genotypes exhibited different protein patterns of a total of 24 protein bands, 11 out of them were common in all tested genotypes. Meanwhile, the variability in the other proteins was due to salinity stress and/or the genetic differences between the tested genotypes. The presence of different patterns of soluble protein in peanut genotypes having different degrees of salt tolerance strengthens the view that salt tolerance or sensitivity depends on the genetic and biochemical makeup of the genotype. Similar conclusions were reported by Dubey (1994) and Rashed et al., (1994).

Generally, the results revealed marked changes in protein patterns as a result of salinity treatment. Under salinity stress, several polypeptides were apparently suppressed whereas others were induced (Table 6 and Fig. 3). Salinity stress induced two proteins at RF 0.931 and 0.816 in all tested varieties. While, one additional band at RF 0.378 in Giza-5 and other band at RF 0.532 in Giza-7 were induced under salinity stress. These results showed that salinity-stress induced the synthesis of 4 new protein bands in all tested genotypes, as compared 
to their control treatment. Most of these newly synthesized proteins were of high Rf values (low molecular weights) and may be involved in the mechanism(s) of salt tolerance in peanut. Hassanein (1999) reported that peanut plants grown under $\mathrm{NaCl}$ showed the induction of 127 and $52 \mathrm{kDa}$ polypeptides. Protein pattern of a salinity-tolerant Arachis hypogaea L. callus cell line was compared with its sensitive counterpart by Jain et al., 2006. They detected several low molecular weight proteins as being unique or significantly elevated in the tolerant line. They suggested that these proteins may play an important role in mediating salinity stress responses in peanut.

In addition to these newly synthesized proteins, salinity stress also suppressed or reduced the production of 5 proteins at Rf 0.091, 0.197, 0.245, 0.284, 0.877 in Giza-7, and 3 protein bands at Rf $0.230,0.437,0.509$ in Gregory. These results revealed that the expression of 8 types of protein bands was suppressed under salinity stress in Gregory and Giza-7 while protein suppression not detected in Giza-5. Hassanein (1999) reported that peanut plants grown under $\mathrm{NaCl}$ showed the suppression of 260 and $38 \mathrm{kDa}$ polypeptides. Ramagopal and Carr (1991) found that salinity stress reduced the expression of 3 proteins and 8 mRNAs in suspension cultures of sugarcane.

Evidently, salinity stress treatment lead to differential expression of the genetic information in peanut, resulting in changes in gene products, including induced the synthesis of certain proteins (4 bands) and simultaneously reduced the expression of other protein sets ( 8 bands) in the tested genotypes. Similar modifications in gene expression under salinity stress had been observed in peanut (Hassanein, 1999; Jain et al., 2006). Stress tolerance in plants has long been accepted as a multigenetic trait dependent on the coordinated expression of certain genes and the silencing of others (Hare et al., 1996).

\section{References:}

Ben-Hayyim, G. and Goffer, Y. (1989). plant regeneration from a $\mathrm{NaCl}$ selected salt-tolerant callus culture of shamouti organe (Citrus sinensis L. Osbeck). Plant Cell Rep., 7: 680-683.

Buiatti, E., Barchielli, A., Geddes, M. (1984). Risk factors in male infertility: a case-control study. Archs Environ. Hlth. ,4 , 266-270.

Cano, E.A.; Perez, A.; Moreno, V. and Bolarin, M. (1996). Responses to $\mathrm{NaCl}$ stress of cultivated and wild tomato species and their hybrids in callus cultures. Plant Cell Reports 15 (10): 791-794.

Dubey, R.S. (1994). Protein synthesis under stressful conditions. In: "Handbook of Plant and Crop Stress", (Eds.), Pessarakli, M., pp. 277-299, Marcel Dekker, Inc., New York.

El-Aref, H.M. (2002). In vitro selection of salt-tolerant tomato plants and the changes in gene expression under salinity stress. Assiut J. Agric. Sci. ,2002, 33(1):23-46.

Feng-zhen, L., Yong-shan, W. and Hong-gang, W. (2003). Effect of Additional $\mathrm{NaCl}$ Concentration in Medium on Growth of Peanut in Vitro Culture. J. Peanut Sci., 4:167-180.

Ghauri, E.G. (2006). Regeneration and acclimatization of salt-tolerant Arachis hypogaea plants through tissue culture. Pakistan J. of Scientific and Industrial Res. 49(3): 203-210. 
Gohari, A.A. and Niyaki, S.A.N. (2010). Effects of iron and nitrogen fertilizers on yield and yield components of peanut (Arachis hypogaea L.) in astaneh ashrafiyeh, Iran. Am. Eur. . J. Agric. Environ. Sci., 9: 256-262.

Hare, P.D., Plessis, S.d., Cress, W.A. and Staden, J.v. (1996). Stress-induced changes in plant gene expression. South African J. Sci. 92:431-439.

Hassanein, A.M. (1999). Alterations in protein and esterase patterns of peanut in response to salinity stress. Biologia Plantarum, 42(2): 241-248.

Jain, S., Srivastava, S., Sarin, N.B. and Kav, N.N.V. (2006). Proteomics reveals elevated levels of PR 10 proteins in saline-tolerant peanut (Arachis hypogaea) calli. Plant Physiol. and Biochem., 44:253-259.

Khavkin, E.E. and Zabrodina, M.V. (1994). Heritable variation in peroxidase and esterase isoen- zyme patterns of maize somaclone. Fiziol. Rast., 41:754-761.

Kirti, P., Hadi, S., Kumar, P. and Chopra, V. (1991). Production of sodiumchloride-tolerant Brassica juncea plants by in vitro selection at the somatic embryo level. Theo. Appl. Genet., 83: 233-237.

Kumar, P., Ghosh, P.D. and Maity, S.S. ( 2001). In vitro selection of salt tolerant variants in Arachis hypogaea L. Indian J. Plant Physiol., 6(3): 323-325.

Laemmli, U.K. (1970). Cleavage of structural proteins during the assembly of the head of bacteriophage T4. Nature 227:680-685.

McCoy, T.J. (1987). Tissue culture evaluation of $\mathrm{NaCl}$ tolerance in Medicago species: Cellular versus whole plant response. Plant Cell Rep., 6: 31-34.

Meredith, C.P. (1984). Selecting better crops from cultured cells In: Gustafason JP (ed) Gene amplification in plant improvement. Plenum press. New Yourk, 503-528.

Mungala, A.J., Radhakrishnan, T. and Dobaria, J.R. (2008). In vitro Screening of 123 Indian Peanut Cultivars for Sodium Chloride Induced Salinity Tolerance.World J. Agri. Sci., 4: 574-582.

Muthukumarasamy, M. and Panneerselvam, R. (1997). Amelioration of $\mathrm{NaCl}$ stress by triadimefon in peanut seedlings. Plant Growth Regulation, 22(3): $157-162$.

Orton, T.J. (1980). Comparison of salt tolerance between hordeum vulgare and hordeum jubatum in whole plants and callus cultures. Zeitschrift Fuer Pflanzenphysiologie: 105-118

Ramagopal, S. and Carr, J.B. (1991). Sugarcane proteins and messenger RNAs regulated by salt in suspension cells. Plant Cell and Environ., 14:47-56.

Rashed, M.A., Fahmy, E.M. and Sallam, M.A. (1994). Embryo culture, protein and isozyme electrophoresis as selectable markers to predict salt tolerance in wheat. $5^{\text {th }}$ Conf. Agric. Dev. Res. Fac. Agric., Ain Shams Univ., Cairo, Egypt, 1: $469-490$.

Sarin, N.B., Gupta, A., Prakash, S. and Biswas, B. (1991). Isolation and characterization of a salt-tolerant line of Arachis hypogaea using in vitro cultures. Acta Horti., 289:219-222.

Taghian, A. S. (1992). Microspore culture techniques in barley for in vitro selection of resistance to fusaric acid or for salinity tolerance. Ph.D. theses, Faculty of Agriculture, Assiut University, Assiut, Egypt. 
Tal, M. (1984). Selection for stress tolerance. In: Handbook of cell culture. Techniques for propagation and breeding. Ammirato, and Yamada Y (eds), 1.Collier Macmillan publishers. London, pp. 461-488.

Xiao-hui, H., Ling-qiang, S., Hua-rong, M., Yun-qing, S. and Jing, C. (2011). Effects of Different $\mathrm{NaCl}$ Concentrations on Indicators for Evaluating Salt Tolerance of Peanut Varieties. Shandong Agric. Sci. 11.

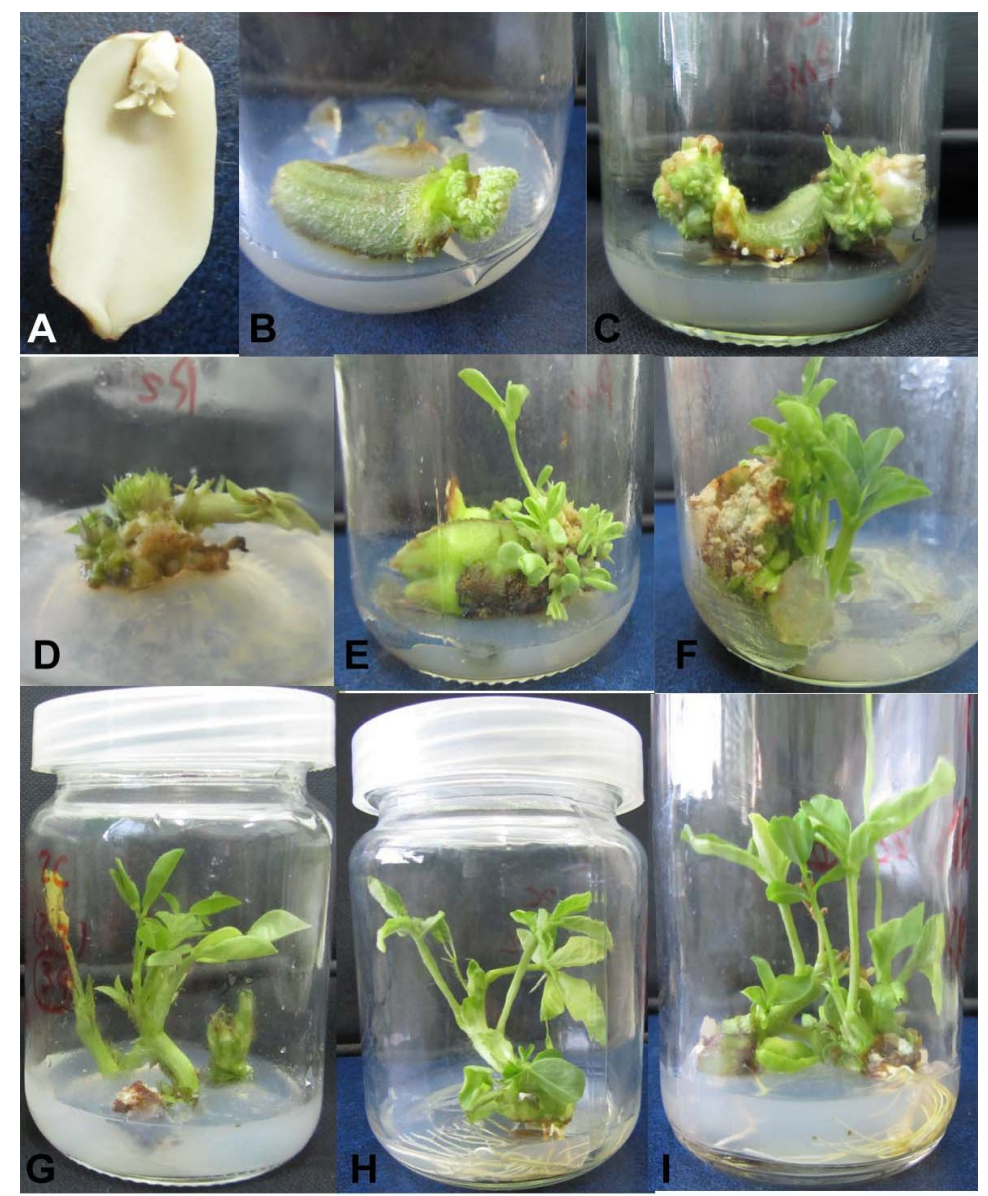

Figure (1): peanut tissue culture where: (A) the embryonated explant, $(B, C)$ explants with developed callus and adventitious bud formation, (D) explant with adventitious bud formation and small shoots expansion, (E, F) adventitious shoot regeneration after 3-6 weeks of culture on regeneration medium, $(\mathrm{G})$ shoots excised and transferred to rooting medium and $(\mathrm{H}, \mathrm{I})$ root development after 4 weeks on root induction medium. 
Table (1): Mean values of callus percentage and number of shoots per explant developed from embryonated cotyledons of six peanut genotypes cultured on control $(0.0 \mathrm{NaCl})$ and salinized (50, 100, 150 and $200 \mathrm{mM} \mathrm{NaCl}$ ) medium.

\begin{tabular}{|c|c|c|c|c|c|c|c|c|}
\hline \multirow{2}{*}{$\begin{array}{l}\mathrm{NaCl} \\
\text { level }\end{array}$} & \multirow{2}{*}{$\begin{array}{l}\text { T.C re- } \\
\text { sponse }\end{array}$} & \multicolumn{6}{|c|}{ Genotypes } & \multirow{2}{*}{ MEAN } \\
\hline & & Ismailia-1 & Giza-5 & Agryl & Gregory & Giza-7 & Giza-6 & \\
\hline \multirow{2}{*}{0.0} & Callus \% & & .33 & 63.33 & 83.33 & 76.67 & 56.67 & 68.33 \\
\hline & Shoots/exp. & & 11.63 & 8.9 & & & & 10.15 \\
\hline \multirow{2}{*}{50} & Callus \% & $\begin{array}{c}53.33 \\
(114.27 \%)\end{array}$ & $\begin{array}{c}81.33 \\
(97.60 \%)\end{array}$ & $\begin{array}{c}66.67 \\
(105.27 \%)\end{array}$ & $\begin{array}{c}56.67 \\
(68.01 \%) \\
\end{array}$ & $\begin{array}{c}46.67 \\
(60.87 \%)\end{array}$ & $\begin{array}{r}43.3 \\
(76.46 \\
\end{array}$ & \\
\hline & Shoots/exp. & $\begin{array}{c}5.86 \\
(72.17 \%)\end{array}$ & $\begin{array}{c}9.67 \\
(83.15 \%)\end{array}$ & $\begin{array}{c}4.67 \\
(52.47 \%)\end{array}$ & $\begin{array}{c}9.67 \\
(80.58 \%)\end{array}$ & $\begin{array}{c}6.60 \\
(60.94 \%)\end{array}$ & $\begin{array}{r}6.1 \\
(65.21 \\
\end{array}$ & $\begin{array}{c}7.10 \\
(69.95 \%)\end{array}$ \\
\hline \multirow{2}{*}{100} & Callus \% & $\begin{array}{c}10.00 \\
(21.43 \%)\end{array}$ & $\begin{array}{c}60.00 \\
(72.00 \%)\end{array}$ & $\begin{array}{c}13.33 \\
(21.05 \%)\end{array}$ & $\begin{array}{c}23.33 \\
(27.99 \%)\end{array}$ & $\begin{array}{c}43.33 \\
(56.51 \%)\end{array}$ & $\begin{array}{r}26 . \\
(47.0\end{array}$ & $\begin{array}{c}29.44 \\
(43.08 \%)\end{array}$ \\
\hline & Shoots/exp. & $\begin{array}{c}1.33 \\
(16.38 \%)\end{array}$ & $\begin{array}{c}6.17 \\
(53.05 \%)\end{array}$ & 1.83 & $\begin{array}{c}4.11 \\
(34.25 \%) \\
\end{array}$ & $\begin{array}{c}3.83 \\
(35.36 \%)\end{array}$ & $\begin{array}{r}3.2 \\
(34.2 \\
\end{array}$ & $\begin{array}{c}3.42 \\
(33.69 \%) \\
\end{array}$ \\
\hline \multirow{2}{*}{150} & Callus \% & $\begin{array}{c}4.33 \\
(9.28 \%)\end{array}$ & $\begin{array}{c}16.67 \\
(20.00 \%)\end{array}$ & $\begin{array}{c}3.00 \\
(4.74 \%)\end{array}$ & $\begin{array}{c}13.33 \\
(15.99 \%)\end{array}$ & $\begin{array}{c}21.67 \\
(28.26 \%)\end{array}$ & $\begin{array}{c}15.00 \\
(26.47 \%)\end{array}$ & $\begin{array}{c}12.33 \\
(18.04 \%)\end{array}$ \\
\hline & Shoots/exp. & $\begin{array}{c}0.30 \\
(3.69 \%)\end{array}$ & $\begin{array}{c}1.6 \\
(13.76 \%)\end{array}$ & $\begin{array}{c}0.27 \\
(3.03 \%)\end{array}$ & $\begin{array}{c}1.37 \\
(11.42 \%)\end{array}$ & $\begin{array}{c}1.43 \\
(13.20 \%)\end{array}$ & $\begin{array}{c}1.20 \\
(12.77 \%)\end{array}$ & $\begin{array}{c}1.03 \\
(10.15 \%)\end{array}$ \\
\hline & Callus \% & $\begin{array}{c}0.10 \\
(0.21 \%) \\
\end{array}$ & $\begin{array}{c}1.75 \\
(2.10 \%) \\
\end{array}$ & $\begin{array}{c}0.76 \\
(1.20 \%) \\
\end{array}$ & $\begin{array}{c}2.00 \\
(2.40 \%) \\
\end{array}$ & $\begin{array}{c}6.67 \\
(8.69 \%) \\
\end{array}$ & $\begin{array}{c}1.67 \\
(2.95 \%) \\
\end{array}$ & $\begin{array}{c}2.13 \\
(3.12 \%) \\
\end{array}$ \\
\hline & Shoots/exp. & $\begin{array}{c}0.1 \\
(1.23 \%)\end{array}$ & $\begin{array}{c}0.47 \\
(4.04 \%) \\
\end{array}$ & $\begin{array}{c}0.17 \\
(1.91 \%)\end{array}$ & $\begin{array}{c}0.43 \\
(3.58 \%)\end{array}$ & $\begin{array}{c}0.47 \\
(4.34 \%) \\
\end{array}$ & $\begin{array}{c}0.30 \\
(3.19 \%) \\
\end{array}$ & $\begin{array}{c}0.32 \\
(3.15 \%) \\
\end{array}$ \\
\hline
\end{tabular}

Table (2): The analysis of variance for callus percentage and number of shoots per explant regenerated on $0.0,50,100,150$ and $200 \mathrm{mM}$ $\mathrm{NaCl}$ stressed media

\begin{tabular}{|c|c|c|c|}
\hline S.V. & Df & $\begin{array}{c}\text { Callus\% } \\
\text { M.S. }\end{array}$ & $\begin{array}{c}\text { Shoots/exp. } \\
\text { M.S. }\end{array}$ \\
\hline Replicates & 2 & 29.744 & $3.562^{*}$ \\
\hline Genotypes & 5 & $1262.536^{* *}$ & $20.387^{* *}$ \\
\hline NaCl Conc. & 4 & $14745.868^{* *}$ & $311.759^{* *}$ \\
\hline G*Conc. & 20 & $334.548^{* *}$ & $2.576^{* *}$ \\
\hline Error & 58 & 24.549 & 0.866 \\
\hline
\end{tabular}

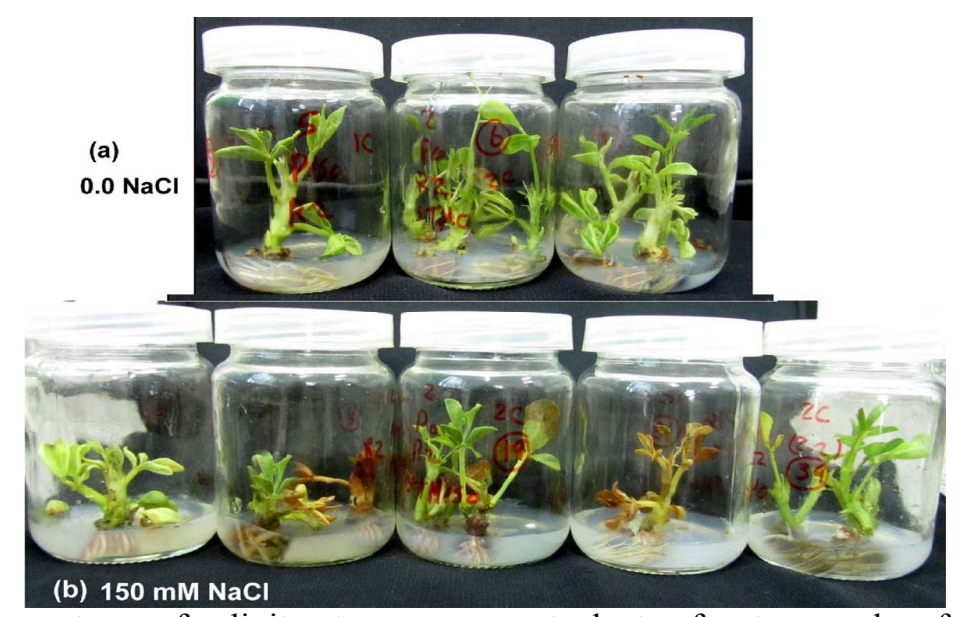

Figure (2): The symptoms of salinity stress on peanut plants after two weeks of growth on culture medium supplemented with $0.0 \mathrm{mM} \mathrm{NaCl}$ (a) and $150 \mathrm{mM} \mathrm{NaCl}$ (b). 
Table (3): The numbers of cultured explants and, callus, shoot and root formation from four peanut genotypes cultured on media supplemented with 0.0 and $150 \mathrm{mM} \mathrm{NaCl}$.

\begin{tabular}{|c|c|c|c|c|c|}
\hline & \multicolumn{3}{|c|}{ Peanut varieties } & \multirow{2}{*}{ MEAN } \\
\cline { 2 - 5 } & Giza-5 & Gregory & Giza-7 & Giza-6 & \\
\hline Medium with 0.0 mM NaCl & & & & & \\
\hline No. of cultured explants & 200 & 200 & 200 & 200 & 200 \\
\hline No. of explants produced callus & 133 & 139 & 106 & 88 & 116.50 \\
\hline \% of callus formation & 66.5 & 69.5 & 53.0 & 44.0 & 58.25 \\
\hline No. of shoots & 1344 & 1440 & 988 & 748 & 1130.00 \\
\hline No. of shoots/explants & 10.11 & 10.36 & 9.32 & 8.5 & 9.57 \\
\hline No. of rooted shoots & 417 & 562 & 396 & 435 & 452.50 \\
\hline \% of rooting & 31.03 & 39.03 & 40.01 & 58.16 & 42.06 \\
\hline Medium with 150 mM NaCl & & & & & \\
\hline No. of cultured explants & 440 & 440 & 440 & 440 & 440.00 \\
\hline No. of explants produced callus & 72 & 61 & 93 & 68 & 73.50 \\
\hline \% of callus formation & 16.36 & 13.86 & 21.14 & 15.45 & 16.70 \\
\hline No. of shoots & 118 & 86 & 138 & 85 & 106.75 \\
\hline No. of shoots/explants & 1.64 & 1.41 & 1.48 & 1.25 & 1.45 \\
\hline No. of rooted shoots & 32 & 28 & 46 & 36 & 35.50 \\
\hline \% of rooting & 27.12 & 32.56 & 33.33 & 42.35 & 33.84 \\
\hline
\end{tabular}

Table (4): Mean increase in plant fresh weight for the selected and unselected plants and their donor parents after two weeks of growth on control $(0.0 \mathrm{NaCl})$ and salinized $(150 \mathrm{mM} \mathrm{NaCl})$ treatments:

\begin{tabular}{|c|c|c|c|c|c|c|c|}
\hline \multirow{2}{*}{ Genotypes } & \multirow{2}{*}{$\begin{array}{l}\mathrm{NaCl} \\
\text { level } \\
\mathrm{mM}\end{array}$} & \multicolumn{2}{|c|}{ Donor parents } & \multicolumn{2}{|c|}{ Selected plants } & \multicolumn{2}{|c|}{ Unselected plants } \\
\hline & & (gram) & $\%$ of control & (gram) & $\%$ of control & (gram) & $\%$ of control \\
\hline \multirow{2}{*}{ Giza-5 } & 0.0 & 1.30 & & 1.29 & & 1.16 & \\
\hline & 150 & 0.80 & 61.54 & 0.93 & 72.09 & 0.74 & 63.79 \\
\hline \multirow{2}{*}{ Gregory } & 0.0 & 1.68 & & 1.96 & & 1.64 & \\
\hline & 150 & 0.89 & 52.98 & 1.09 & 55.61 & 0.88 & 53.66 \\
\hline \multirow{2}{*}{ Giza-7 } & 0.0 & 1.80 & & 1.56 & & 1.67 & \\
\hline & 150 & 1.10 & 61.11 & 1.32 & 84.61 & 0.96 & 57.48 \\
\hline \multirow{2}{*}{ Giza-6 } & 0.0 & 1.60 & & 1.74 & & 1.41 & \\
\hline & 150 & 0.85 & 53.13 & 1.37 & 78.74 & 0.79 & 56.03 \\
\hline \multirow{2}{*}{ MEAN } & 0.0 & 1.60 & & 1.64 & & 1.47 & \\
\hline & 150 & 0.91 & 56.88 & 1.18 & 71.95 & 0.84 & 57.14 \\
\hline
\end{tabular}

Table (5): The analysis of variance for the mean increase in plant fresh weights for the selected and unselected plants and their donor parents after two weeks of growth on control $(0.0 \mathrm{NaCl})$ and salinized $(150 \mathrm{mM} \mathrm{NaCl})$ treatments.

\begin{tabular}{|c|c|c|c|}
\hline S.V. & Df & M.S. & $\mathbf{F}$ \\
\hline Replicates & 2 & 0.013 & 1.30 \\
\hline Genotypes & 11 & 0.228 & $22.80^{* *}$ \\
\hline Selected vs. unselected & 1 & 2.273 & $227.30^{* * *}$ \\
\hline Selected vs. parents & 1 & 10.619 & $1061.90^{* *}$ \\
\hline Unselected $v$ s. parents & 1 & 0.010 & 1.00 \\
\hline NaCl Conc. & 1 & 6.284 & $628.40^{* * *}$ \\
\hline Genotypes $x$ Conc. & 11 & 0.063 & $6.30^{* *}$ \\
\hline Error & 46 & 0.010 & \\
\hline
\end{tabular}




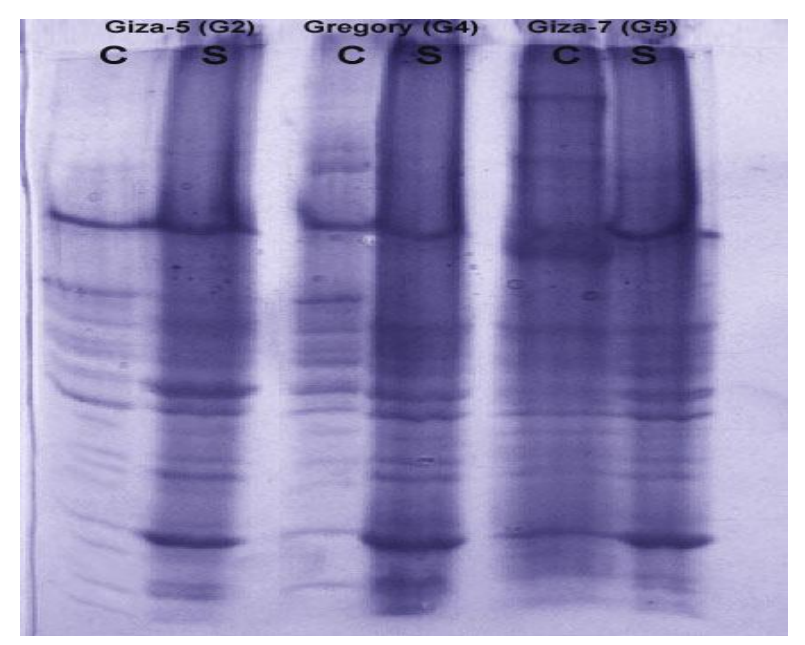

Figure (3): Protein profile of Giza-5, Gregory and Giza-7 treated with 0.0 (C) and $150 \mathrm{mM}(\mathrm{S}) \mathrm{NaCl}$.

Table (6): Protein bands detected $(+)$ in Giza-5, Gregory and Giza-7 treated with 0.0 (C) and $150 \mathrm{mM}(\mathrm{S}) \mathrm{NaCl}$. Data were obtained by GeneProfiler-Eval electrophoresis data system program.

\begin{tabular}{|c|c|c|c|c|c|c|c|c|c|c|c|c|c|c|c|}
\hline \multirow{2}{*}{ No } & \multirow{2}{*}{$\mathbf{R f}$} & \multicolumn{2}{|c|}{ Giza-5 } & \multicolumn{2}{|c|}{ Gregory } & \multicolumn{2}{|c|}{ Giza-7 } & \multirow{2}{*}{ No } & \multirow{2}{*}{ Rf } & \multicolumn{2}{|c|}{ Giza-5 } & \multicolumn{2}{|c|}{ Gregory } & \multicolumn{2}{|c|}{ Giza-7 } \\
\hline & & $\mathrm{C}$ & $\mathbf{S}$ & $\mathrm{C}$ & $\mathbf{S}$ & $\mathrm{C}$ & $\mathbf{S}$ & & & $\mathrm{C}$ & $\mathbf{S}$ & $\mathrm{C}$ & $\mathbf{S}$ & $\mathrm{C}$ & $\mathbf{S}$ \\
\hline 1 & 0.091 & & & & & + & & 13 & 0.592 & + & + & + & + & + & + \\
\hline 2 & 0.197 & & & & & + & & 14 & 0.636 & + & + & + & + & + & + \\
\hline 3 & 0.230 & & & + & & + & + & 15 & 0.668 & + & + & + & + & + & + \\
\hline 4 & 0.245 & & & & & + & & 16 & 0.699 & + & + & + & + & + & + \\
\hline 5 & 0.284 & & & & & + & & 17 & 0.732 & + & + & + & + & + & + \\
\hline 6 & 0.332 & + & + & + & + & + & + & 18 & 0.765 & + & + & & & & \\
\hline 7 & 0.378 & & + & & & & & 19 & 0.816 & & + & & + & & + \\
\hline 8 & 0.437 & + & + & + & & & & 20 & 0.842 & + & + & + & + & + & + \\
\hline 9 & 0.487 & + & + & + & + & + & + & 21 & 0.877 & + & + & & & + & \\
\hline 10 & 0.509 & & & + & & & & 22 & 0919 & + & + & + & + & + & + \\
\hline 11 & 0.532 & + & + & + & + & & + & 23 & 0.931 & & + & & + & & + \\
\hline 12 & 0.551 & + & + & + & + & + & + & 24 & 0.958 & + & + & + & + & + & + \\
\hline No & f bands & & & & & & & & & 15 & 18 & 15 & 14 & 17 & 15 \\
\hline
\end{tabular}




\section{التعبير الجيني والاتخاب في الآبوب لتحمل الملحية فى الفول السوداني}

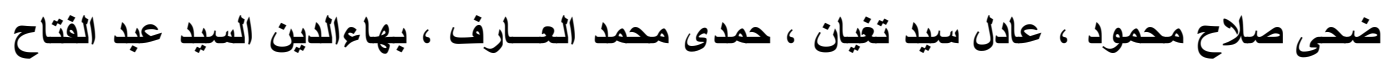

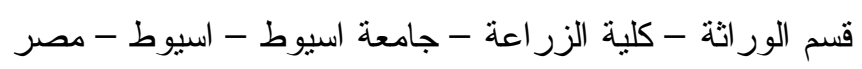

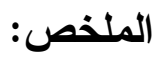

يعتبر الفول السوداني احد المحاصيل الزيتية الهامة في العالم وكنلك في مصر • في هـــه

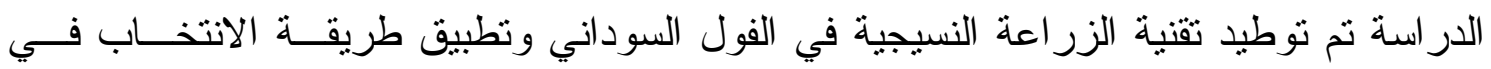

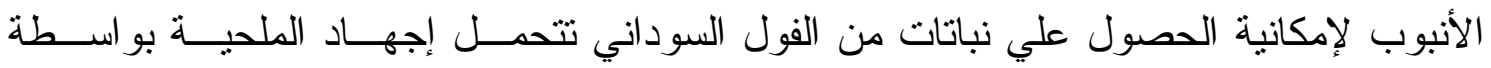
الزر اعة النسيجية. وبالإضافة إلي ذلك تمت دراسة التغير في التعبير الجيني تحت إجهاد الملحية بو اسطة تحليل نماذج البروتينات. حدث انخفاض في تكوين الكالوس وتكثف الأفرع الخـضرية عند زيادة مستوى كلوريد الصوديوم في البيئة من 50 إلى 150 ملي مول ـ في التركيز العـالي

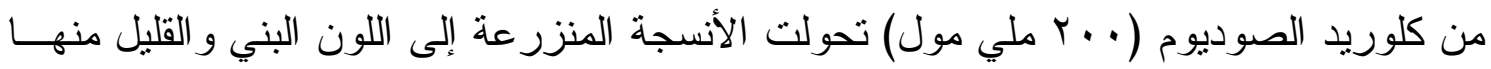

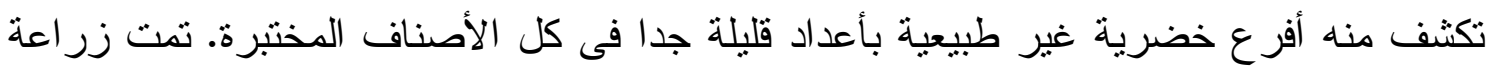

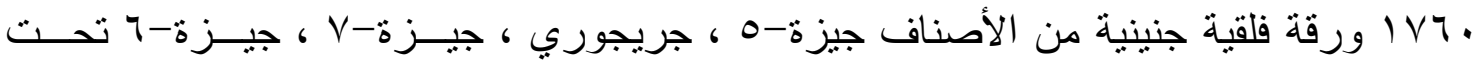

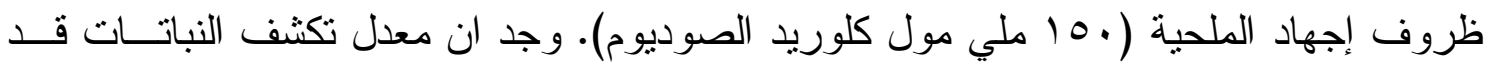
انخفض بشدة تحت إجهاد الملحية مقارنة بمعاملة الكنترول. النباتات المنتخبــة و النباتــات غيــر

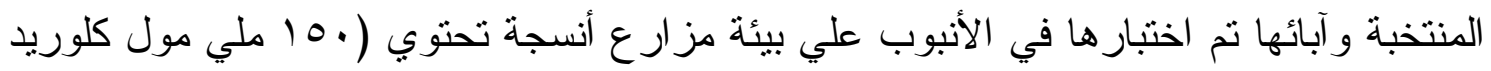

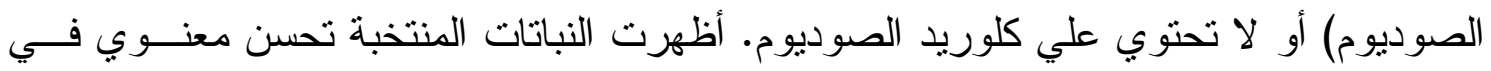
نموها تحت معاملة الملحية مقارنة بالنباتات غير المنتخبة و آبائها.

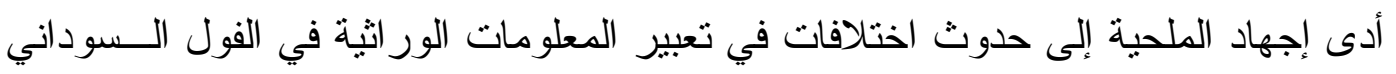
ناتجة من تغير ات في نو اتج الجينات و التي اثتنملت علي استحداث بناء أربعة بروتينات جديــدة ،

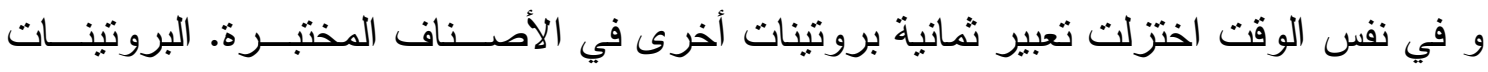
الجديدة ربما تلعب دور اهاما في ميكانيكية تحمل الملحية في الفول السوداني. 